
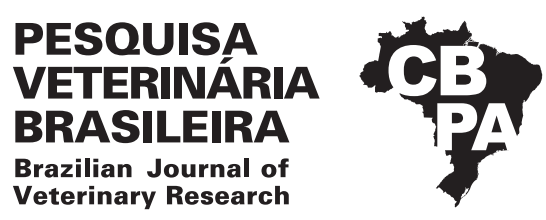

Pesq. Vet. Bras. 38(7):1293-1299, julho 2018 DOI: 10.1590/1678-5150-PVB-4999

Original Article

ISSN 0100-736X (Print)

ISSN 1678-5150 (Online)

\title{
Adherence to and invasion of HeLa cells by Campylobacter spp. strains isolated from animals ${ }^{1}$
}

\author{
Paula Alexandra G. Morais-Rios², Telma M. Alves², Elaine M.S. Dorneles ${ }^{3}$, \\ Ana Paula R. Stynen ${ }^{2}$, Ana Cláudia P. Cottorello ${ }^{2,4}$, Ana Luzia Lauria-Filgueiras ${ }^{5}$ \\ and Andrey P. Lage ${ }^{2 *}$
}

\begin{abstract}
Morais-Rios P.A.G., Alves T.M., Dorneles E.M.S., Stynen A.P.R., Cottorello A.C.P., Lauria-Filgueiras A.L. \& Lage A.P. 2018. Adherence to and invasion of HeLa cells by Campylobacter spp. strains isolated from animals. Pesquisa Veterinária Brasileira 38(7):1293-1299. Laboratório de Bacteriologia Aplicada, Departamento de Medicina Veterinária Preventiva, Escola de Veterinária, Universidade Federal de Minas Gerais, Av. Antônio Carlos 6627, Cx. Postal 567, Belo Horizonte, MG 31270-901, Brazil. E-mail: alage@vet.ufmg.br

The objective of this study was to evaluate the adherence to and invasion of HeLa cells by Campylobacter spp. strains (total $n=63)$ isolated from chickens $(n=4)$, dogs $(n=4)$, non-human primates $(n=16)$, pigs $(n=9)$, calf feces $(n=18)$, and bovine genital tracts $(n=12)$. Thirty-two strains adhered to and 13 invaded HeLa cells. Invasive strains included 1 of 4 dog isolates, 4 of 16 non-human primate isolates ( 2 C. jejuni and 2 C. coli), 1 of 9 C. coli strains isolated from pigs, and 7 of 18 C. fetus subsp. fetus isolated from calf feces. Only $25 \%$ of chicken and dog isolates and $23 \%$ of pig isolates were able to adhere to HeLa cells, a property of $65 \%$ of strains obtained from calf feces and $83 \%$ of bovine genital tract-isolated strains. The adherent phenotype was observed in 5 of 19, 6 of 15, and 21 of 29 strains of $C$. jejuni, C. coli, and C. fetus subsp. fetus, respectively, whereas 3 of 19, 3 of 15, and 7 of 29 strains were additionally able to invade HeLa cells, respectively. C. jejuni, C. coli, and C. fetus subsp. fetus strains isolated from animal feces are able to adhere and invade HeLa cells, whereas C. fetus subsp. fetus strains isolated from the bovine genital tract were not invasive in HeLa cells. The present study showed that $C$. jejuni isolated from primates and dogs, $C$. coli isolated from non-human primates and pigs, and $C$. fetus subsp. fetus isolated from calf feces have the ability to adhere to and to invade HeLa cells. Moreover, the lack of invasive ability by C. fetus subsp. fetus strains isolated from the bovine genital tract could be important in the pathogenesis of the genital tract diseases caused by this bacterium.
\end{abstract}

INDEX TERMS: Adherence, invasion, HeLa cells, Campylobacter spp., chicken, dogs, swine, cattle, domestic animals, non-human primates.

RESUMO.- [Adesão e invasão de células HeLa por amostras de Campylobacter spp. isoladas de animais.] 0 objetivo deste estudo foi avaliar a adesão e invasão de células HeLa

\footnotetext{
${ }^{1}$ Received on January 13, 2017.

Accepted for publication on June 21, 2017.

${ }^{2}$ Departamento de Medicina Veterinária Preventiva, Escola de Veterinária, Universidade Federal de Minas Gerais (UFMG), Cx. Postal 567, Av. Antônio Carlos 6627, Belo Horizonte, MG 31270-901, Brazil. *Corresponding author: alage@vet.ufmg.br

${ }^{3}$ Departamento de Medicina Veterinária, Universidade Federal de Lavras, Cx. Postal 3037, Lavras, MG 37200-000, Brazil.

${ }^{4}$ Laboratório Nacional Agropecuário, Ministério da Agricultura, Pecuária e Abastecimento, Av. Rômulo Joviano, Pedro Leopoldo, MG 33600-000, Brazil.

${ }^{5}$ Departamento de Bacteriologia, Instituto Oswaldo Cruz, Fundação Oswaldo Cruz, Av. Brasil 4365, Manguinhos, Rio de Janeiro, RJ 21040-360, Brazil.
}

por amotras de Campylobacter spp. (total $\mathrm{n}=63$ ) isoladas de frangos $(n=4)$, cães $(n=4)$, primatas não-humanos $(n=16)$, porcos $(n=9)$, fezes de bezerros $(n=18)$, e trato genital de bovinos $(n=12)$. Trinta e duas amostras foram capazes de aderir e 13 invadiram células HeLa. As amostras invasivas incluíram 1 de 4 isolados de cão, 4 de 16 isolados de primatas não-humano (2 C. jejuni e 2 C. coli), 1 de 9 C. coli isoladas de porcos e 7 de 18 C. fetus subsp. fetus isoladas de fezes de bezerros. Apenas $25 \%$ dos isolados de frango e de cão e $23 \%$ dos isolados de suínos foram capazes de aderir a células HeLa, propriedade exibida por $65 \%$ das cepas obtidas a partir de fezes de bezerros e por $83 \%$ das amostras isoladas de trato genital bovino. 0 fenótipo aderente foi observado em 5 de 19,6 de 15 e 21 de 29 amostras de C. jejuni, C. coli e C. fetus subsp. fetus, respectivamente, enquanto que 3 de 19, 3 de 
15 e 7 de 29 amostras foram adicionalmente capazes de invadir as células HeLa, respectivamente. Amostras de C. jejuni, C. coli e $C$. fetus subsp. fetus isoladas de fezes de animais foram capazes de aderir e invadir as células HeLa, enquanto amostras de $C$. fetus subsp. fetus isoladas a partir de amostras de trato genital bovino não foram invasivas, em células HeLa. 0 presente estudo mostrou que amostras de $C$. jejuni isoladas de primatas não-humanos e cães, $C$. coli isoladas de primatas não-humanos e porcos, e $C$. fetus subsp. fetus isolados a partir de fezes de bezerros foram capazes de aderir e invadir células HeLa. Além disso, a falta de capacidade invasiva de amostras de $C$. fetus subsp. fetus isoladas de trato genital bovino pode ser importante na patogênese das doenças das vias genitais causadas por esta bactéria.

TERMOS DE INDEXAÇÃO: Aderência, invasão, células HeLa, Campylobacter spp., frangos, cães, suínos, bovinos, animais domésticos, primatas não-humanos.

\section{INTRODUCTION}

Recently, much attention has been paid to the genus Campylobacter because isolation of its representative species from human, animal, and food samples is becoming increasingly frequent (Ogden et al. 2009, Newell et al. 2010). Campylobacter spp. are considered indigenous intestinal bacteria in most domestic and wild animals, and transmission to humans occurs through the ingestion of contaminated food and water, including non-pasteurized milk and undercooked poultry meat, or by direct contact with contaminated human or animal fecal material (Butzler 2004, Newell et al. 2010). Therefore, Campylobacter spp. is considered an important zoonotic agent. Pigs, cattle, dogs, cats, and both domestic and wild birds may be considered important reservoirs for Campylobacter spp. and thus possible sources of infection for humans. Infection with $C$. jejuni in humans is also associated with the development of Guillain-Barré syndrome (Nyati \& Nyati 2013). C. jejuni and C. coli cause enterocolitis in humans, and $C$. fetus may cause not only bacteremia in immunodeficient individuals but also abortion and infertility in ruminants (Butzler 2004, Alves et al. 2011).

Interest in Campylobacter infections has increased because they are now widely seen as a public health issue. Some Campylobacter sp. cause enterocolitis in humans in both industrialized and developing countries. Enteric infections by $C$. jejuni and $C$. coli are among the main public health problems in industrialized countries (Butzler 2004, CDC 2012). In developing countries, the infection is frequently reported in children and is often asymptomatic due to immunity arising from frequent exposure to Campylobacter spp. (Ketley 1997).

Microbiological studies performed in Brazil have reported the isolation of Campylobacter spp. from chickens, calves, tamarins, and children with and without diarrhea, demonstrating the high isolation frequency of Campylobacter spp. in the country (Mendes 1985, Dias et al. 1990, Lage et al. 1992, Carvalho et al. 2001, Aquino et al. 2010, Quetz et al. 2012). Factors associated with the pathogenicity of Campylobacter spp. include the abilities to invade epithelial cells and produce enterotoxin and cytotoxin (Ketley 1997, Zilbauer et al. 2008, Dasti et al. 2010, O'Croinin \& Backert 2012). Many enteric pathogens, including Campylobacter spp., try to evade the host defense system and penetrate epithelial cells, thus causing inflammation, cell death, and bacteremia. The ability of Campylobacter spp. strains to adhere to and invade epithelial cells is considered the most important pathogenic mechanism of diarrhea by Campylobacter spp. (Ketley 1997, Dasti et al. 2010, O'Croinin \& Backert 2012) and has been previously tested in several ways (Manninen et al. 1982, Fauchere et al. 1986, Fernandez \& Trabulsi 1995, Graham 2002). Among these techniques, the gentamicin protection assay is used by many scientists to quantify the cell-associated and intracellular bacterial population and is considered to be the most precise of all detection methods (Melo et al. 1989, Konkel et al. 1992, Russell \& Blake 1994, Wooldridge et al. 1996). Moreover, genes involved in the cellular invasion process are present in the genome of Campylobacter spp. (Lefebure et al. 2010, Ali et al. 2012).

Most studies concerned with the factors associated with the pathogenicity of Campylobacter spp. are performed with clinical isolates from human patients. Knowledge of the adherence and invasive abilities of strains isolated from domestic animals is scarce. Therefore, this study aimed to evaluate and compare the adherence and invasive abilities of Campylobacter spp. strains isolated from feces of different animal species and from the bovine genital tract.

\section{MATERIALS AND METHODS}

Bacterial strains and culture conditions. Campylobacter spp. strains isolated from bovine genital tract $(n=8)$ and from feces $(n=51)$ of calves, chickens, pigs, dogs, and non-human primates in Brazil and $C$. fetus subsp. fetus strains $(\mathrm{n}=4)$ isolated from bovine genital tracts in Canada were tested (Table 1 ). The $C$. jejuni 84 sp strain was used as invasive positive control, and $C$. coli 49 sp was employed as a non-invasive negative control (Carvalho et al. 2001). All strains isolated were previously identified by routine techniques (Hum et al. 1997, Debruyne et al. 2008). Bacterial strains were cultivated in BHI agar (Difco, Detroit, MI, USA) supplemented with $10 \%$ horse blood at $37^{\circ} \mathrm{C}$ in microaerophilic conditions $\left(5 \% \mathrm{O}_{2}, 5 \% \mathrm{H}_{2}, 10 \% \mathrm{CO}_{2}\right.$, and $80 \% \mathrm{~N}_{2}$ ) for 48 hours. After this initial period, strains were stored at $-70^{\circ} \mathrm{C}$

Table 1. Origin of Campylobacter spp. strains tested for adherence and invasion

\begin{tabular}{|c|c|c|c|c|}
\hline \multirow[b]{2}{*}{ Origin } & \multicolumn{3}{|c|}{ Species } & \multirow[b]{2}{*}{ Total } \\
\hline & C. coli & $\begin{array}{c}\text { C. fetus } \\
\text { subsp. fetus }\end{array}$ & C. jejuni & \\
\hline \multicolumn{5}{|l|}{ Bovine genital tract } \\
\hline Fetus & & 1 & & 1 \\
\hline Bovine genital tract & & 4 & & 4 \\
\hline Preputial washing & & 4 & & 4 \\
\hline Vaginal mucus & & 3 & & 3 \\
\hline \multicolumn{5}{|l|}{ Feces } \\
\hline Calf & & 17 & 1 & 18 \\
\hline Dog & & & 4 & 4 \\
\hline Non-human primate & 9 & & 7 & 16 \\
\hline Poultry & 1 & & 3 & 4 \\
\hline Swine & 5 & & 4 & 9 \\
\hline TOTAL & 15 & 29 & 19 & 63 \\
\hline
\end{tabular}


in thioglycolate broth (Merck, Darmstadt, HE, Germany) containing 20\% glycerol (Mills \& Gherna 1988).

Cell line. The assays were performed with HeLa cells (CCL2, American Type Culture Collection - ATCC, Manassas, VA, USA) kept in minimal essential medium (MEM) (Sigma, St Louis, MO, USA) supplemented with $10 \%$ fetal bovine serum (FBS) (Life Technologies, Carlsbad, CA, USA), 200 IU/ml penicillin G (Sigma, St Louis, MO, USA), and $50 \mu \mathrm{g} / \mathrm{ml}$ streptomycin (Sigma, St Louis, MO, USA). Cells were cultivated in plastic bottles kept in $5 \% \mathrm{CO}_{2}$ at $37^{\circ} \mathrm{C}$ for 24 to 48 hours. The confluent monolayer obtained in the surface of the bottle was trypsinized, diluted 1:3 in MEM with 5\% FBS and antibiotics, and re-incubated in the same conditions.

Adherence and invasion assay. The assay was performed as previously described (Konkel \& Joens 1989), with modifications. A suspension of HeLa cells in MEM supplemented with 5\% FBS without antibiotics $\left(4 \times 10^{5}\right.$ cells $\left./ \mathrm{mL}\right)$ was prepared 18 hours before the beginning of the experiment as follows: to each well of a 48-well plates (Corning Incorporation, Corning, NY, USA), $550 \mu \mathrm{L}$ cell suspension was added, and plates were incubated at $37^{\circ} \mathrm{C}$ in a $5 \% \mathrm{CO}_{2}$ humid atmosphere. After incubation, the medium was removed, and each well was washed ten times with PBS pH 7.2. Bacterial strains were suspended in PBS $\left(10^{8} \mathrm{CFU} / \mathrm{mL}\right.$, equivalent to tube 2 of the MacFarland scale), after cultivation in BHI agar, and centrifuged at $14,000 \mathrm{xg}$ for 10 minutes. The pellet was resuspended in the same volume of MEM with 5\% FBS without antibiotics and inoculated $(140 \mu \mathrm{L})$ into quadruplicate wells of the 48 -well plates. The multiplicity of infection used was 1,000 bacteria/cell. Infected monolayers were incubated for 3 hours at $37^{\circ} \mathrm{C}$ and $5 \% \mathrm{CO}_{2}$ to allow the bacteria to adhere to the cells. After incubation, the medium was removed, and the wells were washed ten times with $500 \mu \mathrm{L}$ PBS. Thereafter, $140 \mu \mathrm{L}$ of MEM with $5 \% \mathrm{FBS}$ and $250 \mu \mathrm{g} / \mathrm{mL}$ gentamicin were added in two of the wells, and the same volume of medium without any antibiotic was added to the other two wells. The plates were then incubated at $37^{\circ} \mathrm{C}$ in a $5 \% \mathrm{CO}_{2}$ humid atmosphere for another 3 hours. After disposal of the medium, the wells were washed ten times with $500 \mu \mathrm{L}$ PBS. Cells were lysed with $200 \mu \mathrm{L} /$ well of $0.1 \%$ Triton X100 (LKB Bromma, Sollentuna, ULF, Sweden) for 10 minutes. Each strain was tested twice, and all tests were done in duplicate. The concentration of the bacterial suspensions was determined in duplicate by the drop count method in BHI agar with 5\% horse blood (Miles et al. 1938).

Strains were considered non-adherent and non-invasive (Ad-/Inv-) when no bacterial growth was detectable during bacterial counts made from the wells with and without gentamicin. Adherent but non-invasive strains (Ad+/Inv-) showed bacterial growth in wells without gentamicin treatment, but bacterial counts were equal or inferior to the negative control counts (strain 49sp) in the wells treated with antibiotic. Conversely, invasive strains (Ad+/Inv+) had bacterial growth in wells without gentamicin treatment and bacterial enumeration in wells treated with gentamicin were higher than the negative control counts. Results are expressed as the average number of bacteria adhering to and invading HeLa cells for two determinations. The percentages of adherence and invasion were calculated as previously described (Tay et al. 1996). The percentage of adherence for each strain was calculated from the bacterial populations of the wells without gentamicin as follows: $\%$ adherence = [(\# intracellular bacteria + adherent bacteria $/ \mathrm{mL}) /(\#$ bacteria in inoculum $/ \mathrm{mL}$ )]x100. The percentage of invasion for each strain was defined using the bacterial count of the wells treated with gentamicin, by the formula: \% of invasion $=[(\#$ intracellular bacteria $/ \mathrm{mL}) /$ (\# bacteria in inoculum/mL)]x100.

Statistical analysis. The association between the ability to adhere to and invade HeLa cells by strains isolated from animals was evaluated by the $\chi^{2}$ test or by Fisher's exact test, where appropriate (Siegel \& Castellan 1979, Sampaio 2002).

\section{RESULTS}

Data for the adherence to and invasion of HeLa cells by Campylobacter spp. strains isolated from animals are shown in Table 2. The average of invasion by the positive control (C. jejuni strain $84 \mathrm{sp}$ ) per well was $5 \times 10^{3}$ bacteria; in comparison, the average of invasion for the negative control (C. coli strain 49 sp) was 51 bacteria $(0.000051 \%)$. All strains with rate of invasion higher than the negative control were considered invasive. The ability to adhere to and invade HeLa cells was very heterogeneous among the strains evaluated. The rate of invasion varied from 128 to $5.58 \times 10^{5}$ bacteria per well $(0.000128 \%$ to $0.55814 \%)$ and the rate of adherence

Table 2. Adherence and invasion of HeLa cells by Campylobacter spp. strains isolated from animals

\begin{tabular}{|c|c|c|c|c|c|}
\hline Species & Host & $\mathrm{Ad}^{-} / \mathrm{Inv}^{-\mathrm{a}}$ & $\mathrm{Ad}^{+} / \mathrm{Inv}^{-\mathrm{b}}$ & $\mathrm{Ad}^{+} / \mathrm{Inv}^{+\mathrm{c}}$ & Total \\
\hline \multirow[t]{5}{*}{ C. jejuni } & Poultry & 2 & 1 & 0 & 3 \\
\hline & Dog & 3 & 0 & 1 & 4 \\
\hline & Swine & 4 & 0 & 0 & 4 \\
\hline & Calf & 0 & 1 & 0 & 1 \\
\hline & Non-human primate & 5 & 0 & 2 & 7 \\
\hline Subtotal & & 14 & 2 & 3 & 19 \\
\hline C. coli & Non-human primate & 5 & 2 & 2 & 9 \\
\hline Subtotal & & 9 & 3 & 3 & 15 \\
\hline \multirow[t]{2}{*}{ C. fetus subsp. fetus } & Calf (feces) & 6 & 4 & $7^{*}$ & 17 \\
\hline & Cattle (genital tract) & 2 & 10 & 0 & 12 \\
\hline Subtotal & & 8 & 14 & 7 & 29 \\
\hline
\end{tabular}

${ }^{a}$ Nonadherent and noninvasive strains, ${ }^{\mathrm{b}}$ adherent and noninvasive strains, ${ }^{\mathrm{c}}$ adherent and invasive strains; ${ }^{*} \mathrm{P}=0.0039$ by the Fisher's exact test among C. fetus groups. 
yielded values between 5.3 and $2.09 \times 10^{6}$ bacteria per well (0.0000053\% and $2.09302 \%)$.

C. fetus subsp. fetus strains of fecal origin had the highest average values for both adherence and invasion rates. In contrast, C. fetus subsp. fetus strains of genital origin had lower averages of adherence and invasion rates when compared to the other strains tested (Fig.1). Among the fecal C. fetus subsp. fetus strains, 24\% (4 of 17) adhered to HeLa cells without invasion $\left(\mathrm{Ad}^{+} / \mathrm{Inv}\right)$, whereas $41 \%$ ( 7 of 17$)$ were invasive $\left(\mathrm{Ad}^{+} / \mathrm{Inv}^{+}\right)$and $35 \%$ (6 of 17) were neither adherent nor invasive ( $\mathrm{Ad}^{-} / \mathrm{Inv}^{-}$). Conversely, 83\% (10 of 12) of the genital C. fetus subsp. fetus isolates adhered without cellular invasion $\left(\mathrm{Ad}^{+} / \mathrm{Inv}\right)$; none were able to invade HeLa cells (Fig.1).

Of 63 strains tested, 32 (51\%) were considered adherent or invasive, of which 19 (59\%) adhered but did not invade $\left(\mathrm{Ad}^{+} / \mathrm{Inv}\right)$ and $13(41 \%)$ adhered to and invaded $\left(\mathrm{Ad}^{+} / \mathrm{Inv}^{+}\right)$ HeLa cells (Table 2).

No strains of Campylobacter spp. isolated from chicken feces were able to invade HeLa cells. Only one out of four Campylobacter spp. strains isolated from dogs was considered $\mathrm{Ad}^{+} / \mathrm{Inv}^{+}$, a single strain of $C$. jejuni. In the same way, one of nine strains $(C$. coli) isolated from pigs was found to be invasive (Table 2).

Adherence ability ( $\left.\mathrm{Ad}^{+} / \mathrm{Inv}^{-}\right)$was present in 2 of 19 $(10.5 \%)$ C. jejuni strains, whereas 3 of $19(15.7 \%)$ invaded $\left(\mathrm{Ad}^{+} / \mathrm{Inv}^{+}\right)$HeLa cells. In regard to the 15 C. coli strains, 3 (20\%) adhered $\left(\mathrm{Ad}^{+} / \mathrm{Inv}\right)$ and another 3 invaded $\left(\mathrm{Ad}^{+} / \mathrm{Inv}^{+}\right) \mathrm{HeLa}$ cells. Adherence of C. fetus was verified in 14 of $29\left(\mathrm{Ad}^{+} / \mathrm{Inv}^{-}\right)$

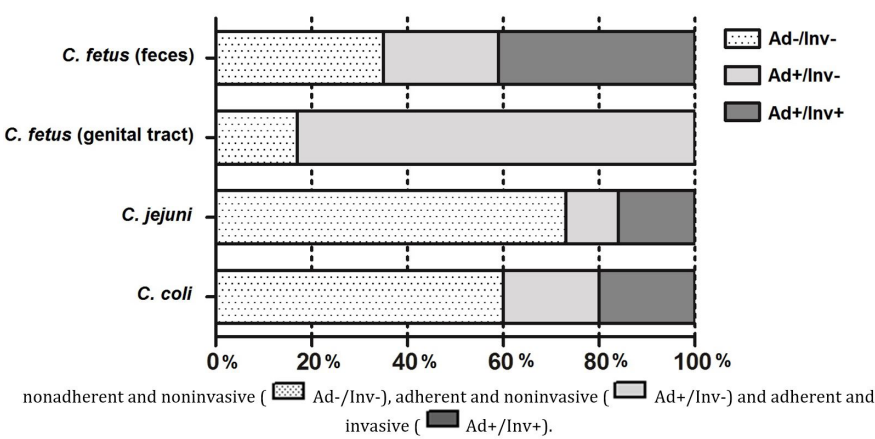

Fig.1. Percentage of different phenotypes of adherence to and invasiveness of HeLa cells for Campylobacter spp. strains isolated from animals. strains, and invasion of HeLa cells was observed in 7 of 29 $\left(\mathrm{Ad}^{+} / \mathrm{Inv}^{+}\right)$strains (Table 2 and Fig.2).

Over half of the $C$. jejuni [73\% (14 of 19)] and C. coli [60\% (9 of 15)] strains did not adhere to or invade HeLa cells (Ad-/Inv'). However, only 28\% (8 of 29) of C. fetus subsp. fetus strains lacked adherence or invasion capability. The cells were not adhered to or invaded (Ad-/Inv) by 35\% (6 of 17) of the intestinal C. fetus subsp. fetus strains and $17 \%$ (2 of 12 ) of the genital strains. There was no significant difference regarding the adherence and invasion abilities of $C$. jejuni and $C$. coli strains isolated from animals. The only significant difference between adherence and invasive abilities was between fecal and genital isolates of $C$. fetus subsp. fetus strains (Fisher's exact test, $\mathrm{P}=0.0039$ ) (Table 2).

Table 3 shows that among the 16 strains isolated from non-human primates, 2 of 7 C. jejuni strains and 2 of 9 C. coli strains were invasive $\left(\mathrm{Ad}^{+} / \mathrm{Inv}^{+}\right)$. Of the 7 C. jejuni strains isolated from these animals, four were isolated from Callithrix penicillata kept in a bioterium at the Center of the Institute of Biological Sciences, UFMG, during a diarrhea outbreak, and

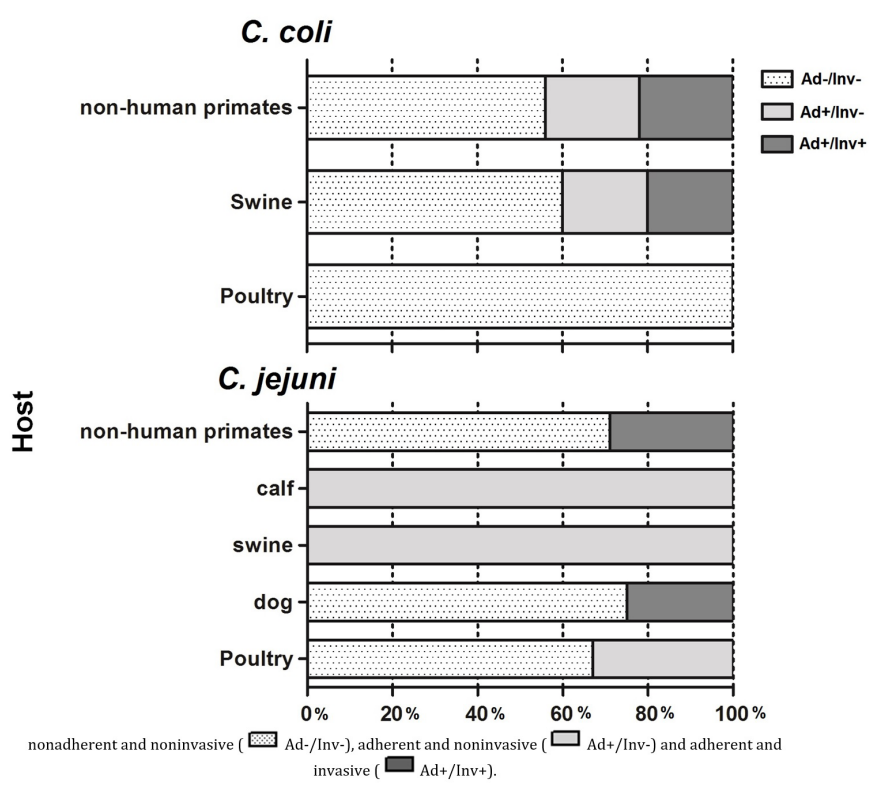

Fig.2. Percentage of different phenotypes of adherence to and invasiveness of HeLa cells for Campylobacter coli and C. jejuni strains isolated from animals.

Table 3. Adherence and invasion of HeLa cells by Campylobacter spp. strains isolated from non-human primates

\begin{tabular}{|c|c|c|c|c|c|}
\hline Species & Host & $\mathrm{Ad}^{-} / \mathrm{Inv}^{-\mathrm{a}}$ & $\mathrm{Ad}^{+} / \mathrm{Inv}^{-\mathrm{b}}$ & $\mathrm{Ad}^{+} / \mathrm{Inv}^{-\mathrm{c}}$ & Total \\
\hline \multirow[t]{3}{*}{ C. jejuni } & Macaca mulatta & 1 & 0 & 0 & 1 \\
\hline & M. fascicularis & 2 & 0 & 0 & 2 \\
\hline & C. penicillata & 0 & 2 & 2 & 4 \\
\hline C. coli & M. mulatta & 2 & 2 & 1 & 5 \\
\hline TOTAL & & 8 & 4 & 4 & 16 \\
\hline
\end{tabular}

a Nonadherent and noninvasive strains, ${ }^{\mathrm{b}}$ adherent and noninvasive strains, ${ }^{\mathrm{c}}$ adherent and invasive strains. 
three were isolated from Macaca mulatta and M. fascicularis kept in the Center for Laboratory Animals (Cecal/Fiocruz, RJ) during regular management. All C. coli strains were isolated from the latter animals.

Half of the $C$. jejuni strains isolated from $C$. penicillata adhered to and invaded the HeLa cells. No $C$. jejuni isolate from animals of the Cecal/Fiocruz, RJ (M. mulatta $\mathrm{n}=2 ;$ M. fascicularis $\mathrm{n}=1$ ) was adherent or invasive $\left(\mathrm{Ad}^{-} / \mathrm{Inv}^{-}\right)$.

of the nine $C$. coli strains retrieved from non-human primates kept in the Cecal/Fiocruz, RJ, two strains (one isolated from $M$. mulatta and another from $M$. fascicularis) were adherent and invasive $\left(\mathrm{Ad}^{+} / \mathrm{Inv}^{+}\right)$. An adherence-only phenotype $\left(\mathrm{Ad}^{+} / \mathrm{Inv}^{-}\right)$was found in two $C$. coli strains isolated from $M$. mulatta, whereas three isolates from $M$. fascicularis and two isolates from $M$. mulatta did not adhere to HeLa cells $\left(\mathrm{Ad}^{-} / \mathrm{Inv}^{-}\right)$.

\section{DISCUSSION}

The invasion of eukaryotic cells is a critical step in the pathogenesis of many bacterial infections. The adherence and invasion assay used in this study is generally accepted as an in vitro method to determine the in vivo adherence and invasion abilities by several enteric pathogens (Konkel \& Joens 1989).

The percentage of invasion for the negative control used in this study (C. coli 49 sp) ( $0.000051 \%$ ) was higher than that reported by Tay et al. (1996) (0.0000039\%), which used HEp-2 cells and E. coli $\mathrm{K} 12$ as negative control. Campylobacter coli, however, is a much better negative control for invasiveness of Campylobacter spp. than Escherichia coli.

There was great variation among the HeLa adherence and invasion abilities of the studied strains. A similar study tested clinical isolates and strains isolated from Malayan domestic birds in HEp-2 cells and found internalization indexes from $0.00078 \%$ to $0.0091 \%$ and adherence indexes from $0.000006 \%$ to $0.045 \%$ (Tay et al. 1996). All six of these strains adhered to HEp- 2 cells, and four were able to invade. The strains isolated from animals in our study had lower adherence and invasion indices, with percentages close to those found by Tay et al. (1996), although some strains had higher percentages of adherence and invasion. Examination of the adherence and invasion capabilities of 173 Campylobacter jejuni and $C$. coli strains isolated from Canadian domestic birds were tested using INT-407 cells and a gentamicin protection assay (Nadeau et al. 2003); the results showed that $19 \%$ of the strains were invasive. Our study found that $25 \%$ of the strains isolated from poultry were able to adhere to HeLa cells but none were invasive. The difference found between the previous study and the present one may be related to the small number of strains tested, the different kind of cell line used in the tests, or the geographical differences of the animals from which the Campylobacter spp. strains were isolated.

Less than half of $C$. jejuni and $C$. coli strains isolated from animals in this study adhered to HeLa cells $\left(\mathrm{Ad}^{+} / \mathrm{Inv}^{-}\right)$. This is in agreement with a previous report that studied invasion of HeLa cells by $C$. jejuni and $C$. coli strains isolated from humans (Fauchere et al. 1986). However, other researchers have reported that all $C$. jejuni and $C$. coli strains isolated from animals were able to adhere to and invade HeLa cells (Manninen et al. 1982, Fernandez \& Trabulsi 1995). This discrepancy may be due to the use of other techniques, such as Giemsa staining and immunofluorescence, respectively, and the small number of strains tested in those studies.

The adherence and invasion abilities of $C$. jejuni and $C$. coli strains isolated from pigs were tested in HEp-2 (Konkel \& Joens 1989) and HeLa cells (Fernandez \& Trabulsi 1995) and considered invasive, despite the low invasion indexes. Only $20 \%$ of the pig $C$. coli isolates in our study were able to invade HeLa cells $\left(\mathrm{Ad}^{+} / \mathrm{Inv}^{+}\right)$; however, no $C$. jejuni strain isolated from pigs was able to adhere to or invade HeLa cells.

Little is known about the pathogenicity of Campylobacter spp. strains isolated from primates. In HEp- 2 cells, the adherence and invasion abilities of $C$. jejuni strains isolated from non-human primates (C. penicillata) during a diarrhea outbreak in the bioterium of the Institut of Biological Sciences-UFMG was reported to be $80 \%$ (Carvalho 1992). Four of those $C$. jejuni strains were included in the current study, $50 \%$ of which tested positive for adherence and invasion. The difference in these results may be related to the number of strains used in this study or by the loss of virulence of these strains during maintenance and replication in the laboratory.

No $C$. jejuni strains isolated from non-human primates during animal management in the Cecal/Fiocruz, RJ, was able to adhere to or invade HeLa cells. Conversely, $22 \%$ of the C. coli strains isolated from these animals were able to invade $\left(\mathrm{Ad}^{+} / \mathrm{Inv}^{+}\right)$; more than half the strains (55\%) did not adhere to or invade HeLa cells ( $\left.\mathrm{Ad}^{-} / \mathrm{Inv}^{-}\right)$. The difference between the results found for $C$. jejuni strains isolated from non-human primates in our study may be due to geographical differences. Another hypothesis to explain this difference is the occurrence of a diarrhea outbreak at the time of isolation of $C$. jejuni from C. penicillata by Carvalho (1992), whereas $C$. jejuni and C. coli strains isolated from M. mulatta and M. fascicularis were obtained during regular animal management, without any instances of diarrhea.

The adherence and invasion abilities of HeLa cells by Campylobacter spp. strains isolated from dogs were previously reported: one strain of $C$. jejuni and one of $C$. coli, both isolated from dogs, were considered invasive (Fernandez \& Trabulsi 1995); another $C$. jejuni strain isolated from a dog was also invasive, as reported elsewhere (Manninen et al. 1982). In contrast, our study tested four $C$. jejuni isolates from dogs, of which only $25 \%$ were able to invade HeLa cells $\left(\mathrm{Ad}^{+} / \mathrm{Inv}^{+}\right)$.

Both $C$. fetus subsp. fetus and $C$. fetus subsp. venerealis may cause disease in cattle, but they colonize different niches. The former colonizes the intestinal tract and may reach the placenta, ultimately resulting in sporadic abortions (Blaser et al. 2008, Alves et al. 2011), whereas the latter inhabits the genital tract and causes reproductive problems, such as repeat breeding, abortions, and sub-fertility (Alves et al. 2011). The adherence and invasion abilities of the fecal $C$. fetus subsp. fetus strains studied here did not correspond to previous findings reported by Graham (2002). In that study, reference $C$. fetus subsp. fetus strains and clinical isolates from human patients were analyzed; all strains tested positive for adherence and invasion, albeit for different incubation times. The differences between the percentages of adherence and invasion regarding the $C$. fetus subsp. fetus strains isolated from either animal feces or the bovine genital tract $(\mathrm{P}=0.0039)$ may be related to differences in pathogenicity between the two subspecies. The $C$. fetus subsp. fetus strains isolated from the intestinal tract are likely able to invade epithelial cells due to the need to 
colonize the host's intestine and evade the intestinal peristaltic movements. In order to cross the intestinal mucosal barrier, interaction with epithelial cells is required (Graham 2002). During C. fetus subsp. fetus colonization of the genital tract, there is no need to invade but only to adhere to epithelial cells, which could be important in the pathogenesis of the genital tract diseases caused by this bacterium.

Our results contrast with findings reported in the literature. First, there are only a few studies regarding adherence and invasion of epithelial cells by Campylobacter spp. isolated from animals, and these studies use a small sampling size. Most reports address adherence and invasion of epithelial cells of human origin (e.g., HeLa cells) by Campylobacter spp. strains isolated from human patients. It has been reported that there is no significant difference in the ability of invasion by Campylobacter spp. strains in distinct human cell lines (INT 407, Hep-2, and HeLa), but only strains isolated from humans were tested (Konkel et al. 1992). There may be a difference in the use of human cell lines when adherence and invasion abilities of Campylobacter spp. strains are tested with animal isolates. Non-human cell lines could possibly express different types or amounts of surface proteins responsible for interaction with Campylobacter spp. Therefore, studies using animal cell lines (e.g., Vero, MDBK, and CHO-K1) and human cell lines to test adherence and invasion by strains retrieved from animals are needed. The small numbers of adherent and invasive Campylobacter spp. strains may also be justified by the number of times the strains tested were passaged in the laboratory. Recent clinical isolates have already been reported to have higher capacities for invasion of epithelial cells than after in vivo passage, which likely lowers this ability (Konkel \& Joens 1989).

\section{CONCLUSIONS}

The present study showed that Campylobacter jejuni isolated from primates and dogs, $C$. coli isolated from non-human primates and pigs, and C. fetus subsp. fetus isolated from calf feces have the ability to adhere to and to invade HeLa cells.

The inability of $C$. fetus subsp. fetus strains isolated from bovine genital tract to invade could be important in the pathogenesis of the genital tract diseases caused by this bacterium.

\section{REFERENCES}

Ali A., Soares S.C., Santos A.R., Guimaraes L.C., Barbosa E., Almeida S.S., Abreu V.A., Carneiro A.R., Ramos R.T., Bakhtiar S.M., Hassan S.S., Ussery D.W., On S., Silva A., Schneider M.P., Lage A.P., Miyoshi A. \& Azevedo V. 2012. Campylobacter fetus subspecies: comparative genomics and prediction of potential virulence targets. Gene 508(2):145-156. <http://dx.doi. org/10.1016/j.gene.2012.07.070> <PMid:22890137>

Alves T.M., Stynen A.P.R., Miranda K.L. \& Lage A.P. 2011. Campilobacteriose genital bovina e tricomonose genital bovina: epidemiologia, diagnóstico e controle. Pesq. Vet. Bras. 31(4):336-344. <http://dx.doi.org/10.1590/ S0100-736X2011000400011>

Aquino M.H., Filgueiras A.L., Matos R., Santos K.R., Ferreira T., Ferreira M.C., Teixeira L.M. \& Tibana A. 2010. Diversity of Campylobacter jejuni and Campylobacter coli genotypes from human and animal sources from Rio de Janeiro, Brazil. Res. Vet. Sci. 88(2):214-217.<http://dx.doi.org/10.1016/j. rvsc.2009.08.005><PMid:19765787>
Blaser M.J., Newell D.G., Thompson S.A. \& Zechner E.L. 2008. Pathogenesis of Campylobacter fetus, p.401-428. In: Nachamkin I., Szymanski C.M. \& Blaser M.J. (Eds), Campylobacter. ASM Press, Washington, DC.

Butzler J.P. 2004. Campylobacter, from obscurity to celebrity. Clin. Microbiol. Infect. 10(10):868-876. <http://dx.doi.org/10.1111/j.1469-0691.2004.00983. $\mathrm{x}><$ PMid:15373879>

Carvalho A.C. 1992. Fatores de virulência de amostras de Campylobacter jejuni isoladas de Callithrix penicillata com diarréia. Minas Gerais, Brasil. Dissertação de Mestrado, Instituto de Ciências Biológicas, Universidade Federal de Minas Gerais, Belo Horizonte, MG. 81p.

Carvalho A.C., Ruiz-Palacios G.M., Ramos-Cervantes P., Cervantes L.E., Jiang X. \& Pickering L.K. 2001. Molecular characterization of invasive and noninvasive Campylobacter jejuni and Campylobacter coli isolates. J. Clin. Microbiol. 39(4):1353-1359. <http://dx.doi.org/10.1128/JCM.39.4.13531359.2001><PMid:11283056>

CDC 2012. Foodborne Diseases Active Surveillance Network (FoodNet): FoodNet surveillance. Report for 2011, Centers for Disease Control and Prevention, Atlanta, Georgia. Available at <https://www.cdc.gov/foodnet/ PDFs/2012_annual_report_508c.pdf> Access on Apr. 12, 2015.

Dasti J.I., Tareen A.M., Lugert R., Zautner A.E. \& Gross U. 2010. Campylobacter jejuni: a brief overview on pathogenicity-associated factors and diseasemediating mechanisms. Int. J. Med. Microbiol. 300(4):205-211.<http:// dx.doi.org/10.1016/j.ijmm.2009.07.002> <PMid:19665925>

Debruyne L., Gevers D. \& Vandamme P. 2008. Taxonomy of the family, p.3-26. In: Nachamkin I., Szymanski C.M. \& Blaser M.J. (Eds), Campylobacter. ASM Press, Washington, DC.

Dias T.C., Queiroz D.M., Mendes E.N. \& Peres J.N. 1990. Chicken carcasses as a source of Campylobacter jejuni in Belo Horizonte, Brazil. Revta Inst. Med. Trop. São Paulo 32(6):414-418.

Fauchere J.L., Rosenau A., Veron M., Moyen E.N., Richard S. \& Pfister A. 1986. Association with HeLa cells of Campylobacter jejuni and Campylobacter coli isolated from human feces. Infect. Immun. 54(2):283-287. <PMid:3770943>

Fernandez H. \& Trabulsi L.R. 1995. Invasive and enterotoxic properties in Campylobacter jejuni and Campylobacter coli strains isolated from humans and animals. Biol. Res. 28(3):205-210. <PMid:9251750>

Graham L.L. 2002. Campylobacter fetus adheres to and enters INT 407 cells. Can. J. Microbiol. 48(11):995-1007. <http://dx.doi.org/10.1139/w02-096> $<$ PMid:12556127>

Hum S., Quinn K., Brunner J. \& On S.L. 1997. Evaluation of a PCR assay for identification and differentiation of Campylobacter fetus subspecies. Aust. Vet. J. 75(11):827-831. <http://dx.doi.org/10.1111/j.1751-0813.1997. tb15665.x><PMid:9404619>

Ketley J.M. 1997. Pathogenesis of enteric infection by Campylobacter. Microbiol. 143(1):5-21. <http://dx.doi.org/10.1099/00221287-143-15><PMid:9025274>

Konkel M.E. \& Joens L.A. 1989. Adhesion to and invasion of HEp-2 cells by Campylobacter spp. Infect. Immun. 57(10):2984-2990. <PMid:2550368>

Konkel M.E., Corwin M.D., Joens L.A. \& CieplakW. 1992. Factors that influence the interaction of Campylobacter jejuni with cultured mammalian cells. J. Med. Microbiol. 37(1):30-37. <http://dx.doi.org/10.1099/00222615-371-30> <PMid:1625313>

Lage A., Carvalho A. \& Leite R. 1992. Comparison of procedures for isolating Campylobacter sp. from diarrheic and normal calves. Revta Microbiol. 23(3):151-154.

Lefebure T., Bitar P.D., Suzuki H. \& Stanhope M.J. 2010. Evolutionary dynamics of complete Campylobacter pan-genomes and the bacterial species concept. Genome Biol. Evol. 2:646-655. <http://dx.doi.org/10.1093/gbe/evq048> $<$ PMid:20688752>

Manninen K.I., Prescott J.F. \& Dohoo I.R. 1982. Pathogenicity of Campylobacter jejuni isolates from animals and humans. Infect. Immun. 38(1):46-52. <PMid:7141696> 
Melo M.A., Gabbiani G. \& Pechère J.C. 1989. Cellular events and intracellular survival of Campylobacter jejuni during infection of HEp-2 cells. Infect. Immun. 57(7):2214-2222. <PMid:2731988>

Mendes E.N. 1985. Frequência de Campylobacter jejuni em crianças com e sem diarréia em Belo Horizonte. Dissertação de Mestrado, Instituto de Ciências Biológicas, Universidade Federal de Minas Gerais, Belo Horizonte, MG. 109p.

Miles A.A., Misra S.S. \& Irwin J.O. 1938. The estimation of the bactericidal power of the blood. J. Hyg. 38(6):732-749. <http://dx.doi.org/10.1017/ S002217240001158X><PMid:20475467>

Mills C.K. \& Gherna R.L. 1988. Cryopreservation studies of Campylobacter. Cryobiology 25(2):148-152. <http://dx.doi.org/10.1016/0011$2240(88) 90008-9><$ PMid:3371059>

Nadeau E., Messier S. \& Quessy S. 2003. Comparison of Campylobacter isolates from poultry and humans: association between in vitro virulence properties, biotypes, and pulsed-field gel electrophoresis clusters. Appl. Environ. Microbiol. 69(10):6316-6320. <http://dx.doi.org/10.1128/ AEM.69.10.6316-6320.2003><PMid:14532099>

Newell D.G., Koopmans M., Verhoef L., Duizer E., Aidara-Kane A., Sprong H., Opsteegh M., Langelaar M., Threfall J., Scheutz F., Van Der Giessen J. \& Kruse H. 2010. Food-borne diseases: the challenges of 20 years ago still persist while new ones continue to emerge. Int. J. Food Microbiol. 139(Suppl. 1):S3-S15. <http://dx.doi.org/10.1016/j.ijfoodmicro.2010.01.021> $<$ PMid:20153070>

Nyati K.K. \& Nyati R. 2013. Role of Campylobacter jejuni infection in the pathogenesis of Guillain-Barre syndrome: an update. Biomed. Res. Int. 2013:852195. <http://dx.doi.org/10.1155/2013/852195><PMid:24000328>

0’Croinin T. \& Backert S. 2012. Host epithelial cell invasion by Campylobacter jejuni: trigger or zipper mechanism? Front Cell Infect. Microbiol. 2:25. <http://dx.doi.org/10.3389/fcimb.2012.00025><PMid:22919617>
Ogden I.D., Dallas J.F., Macrae M., Rotariu O., Reay K.W., Leitch M., Thomson A.P., Sheppard S.K., Maiden M., Forbes K.J. \& Strachan N.J. 2009. Campylobacter excreted into the environment by animal sources: prevalence, concentration shed, and host association. Foodborne Pathog. Dis. 6(10):1161-1170. <http://dx.doi.org/10.1089/fpd.2009.0327><PMid:19839759>

Quetz J.S., Lima I.F.N., Havt A., Prata M.M.G., Cavalcante P.A., Medeiros P.H.Q.S., Cid D.A.C., Moraes M.L., Rey L.C., Soares A.M., Mota R.M.S., Weigl B.H., Guerrant R.L. \& Lima A.A.M. 2012. Campylobacter jejuni infection and virulence-associated genes in children with moderate to severe diarrhoea admitted to emergency rooms in northeastern Brazil. J. Med. Microbiol. 61(Pt 4):507-513. <http://dx.doi.org/10.1099/jmm.0.040600$0><$ PMid:22174372>

Russell R.G. \& Blake Junior D.C. 1994. Cell association and invasion of Caco-2 cells by Campylobacter jejuni. Infect. Immun. 62(9):3773-3779. $<$ PMid:8063393>

Sampaio I.B.M. 2002. Estatística Aplicada à Experimentação Animal. Fundação de Ensino e Pesquisa em Medicina Veterinária e Zootecnia, Belo Horizonte. 265p.

Siegel S.N. \& Castellan J. 1979. Estatistica nao-parametrica para as ciencias do comportamento. Artmed, Porto Alegre. 350p.

Tay S.T., Devi S., Puthucheary S. \& Kautner I. 1996. In vitro demonstration of the invasive ability of Campylobacters. Zentralblatt ür Bakteriologie 283(3):306-313. <http://dx.doi.org/10.1016/S0934-8840(96)80064-8>.

Wooldridge K.G., Williams P.H. \& Ketley J.M. 1996. Host signal transduction and endocytosis of Campylobacter jejuni. Microb. Pathog. 21(4):299-305. <http://dx.doi.org/10.1006/mpat.1996.0063><PMid:8905618>

Zilbauer M., Dorrell N., Wren B.W. \& Bajaj-Elliott M. 2008. Campylobacter jejuni-mediated disease pathogenesis: an update. Trans. R. Soc. Trop. Med. Hyg. 102(2):123-129. <http://dx.doi.org/10.1016/j.trstmh.2007.09.019> <PMid:18023831> 